\title{
ERA DIGITAL \\ (PERGESERAN PARADIGMA DARI HUKUM MODERN KE POST MODERNISME)
}

\author{
Iskandar Wibawa \\ Fakultas Hukum Universitas Muria Kudus \\ J1. Lingkar Utara Gondangmanis Bae Kudus \\ Email: Iskandar.wibawa@yahoo.com
}

\begin{abstract}
Construction law curently built by the flow of positivism, a mega-meta narative, written law whose application using the method syllogisme. This is the paradigm of modern law. The digital age affects the lives of many fielda, incluiding the field of law. The paradigm of modern lawis deemed unable to solve problems that occur in society. A new paradigm for solving the problem, namely the paradigm of Post Moernism, which interprets the law is a legal micro-narative which a law the diversity of legal interpretation. Written law is interpreted in context, and seen as a frame performence problems in society.
\end{abstract}

Keywords: Paradigm; Modern; Post Modernism; Legal Meta-Narative; Legal Micro-Narative.

\begin{abstract}
Abstrak
Konstruksi hukum saat ini dibangun berdasarkan aliran positivisme, merupakaan legal-meta narative yang maujud dalam bentuk hukum tertulis yang penerapannya menggunakan mehhode sylogisme,. Hal ini merupakan paradigma hukum modern. Era digital yang terjadi saat ini mempengaruhi kehidupan diberbagai bidang, termasuk di bidang hukum. Paradigma hukum modern yang positivistik, legal-meta naratuve dan penggunaaan sylogisme mengalami kesulitan menyelesaikan masalah yang terjadi di masyarakat. Paradigma baru diperlukan untuk menyelesaikan masalah tersebut, yaitu paradigma post modernism. Paradigma ini memaknai hukum sebagai legal-micronarative, memberikan peluang adanya keragaman dalam memaknai hukum. Hukum tertulis dimaknai sesuai dengan konteksnya, dan dipandang sebagai bingkai dalam rangka menyelesaikan masalahyang terjadi dalam masyarakat.
\end{abstract}

Kata Kunci: Paradigma; Modern; Post Modernisme; Legal Meta-Narative; Legal-Micro-Narative.

\section{A. Pendahuluan}

Manusia sekarang hidup di peradaban modern yang menuntut segala sesuatu serba cepat, efektif dan efisien. Modern menjadi sebuah identitas yang seolah harus melekat pada semua perangkat kehidupan manusia. Sisanya dianggap kuno, tradisional dan ketinggalan zaman. Perkembangan sains dan teknologi telah menyebabkan pelbagai perubahan di bidang politik, ekonomi, sosial, dan budaya. Salah satu perkembangan sains dan teknologi yang tengah melaju dengan sangat pesat adalah perkembangan di bidang teknologi informasi. Hal ini antara lain ditandai dengan kelahiran internet, yang secara keilmuan disebut sebagai ruang-maya (cyberspace). ${ }^{1}$

Cyberspace menjadi produk digital terkini yang mampu menerobos batas ruang dan waktu, termasuk negara yang selama ini dibatasi oleh wilayah territorial. Menurut Howard Rheingold, cyberscpace adalah sebuah ruang imajiner atau ruang maya yang bersifat artificial, dimana setiap orang melakukan apa saja yang biasa dilakukan dalam kehidupan sosial sehari-hari dengan

1. AP Edi Atmaja, "Kedaulatan Negara Di Ruang Maya: Kritik UU ITE Dalam Pemikiran Satipto Rahardjo", Jurnal Opinio Juris, Vol. 16, Mei-September 2014, hlm 50 
cara-cara yang baru. ${ }^{2}$ Melalui cyberspace, semua orang terhubung melalui international network (internet), dapat saling berinteraksi dengan siapapun, kapanpun, dimanapun.

Cyberspace telah menjelma menjadi ruang publik (publicsphere) sebagaimana diungkapkan oleh Hubermas. Internet menjadi media diskusi publik yang terbuka bagi setiap individu tentang berbagai tema tanpa pembatasan. Cyberspace juga telah mengalihkan kegiatan manusia yang semula dilakukan didunia nyata. Kehadiran email, weblog, chat, webcam sampai dengan facebook dan twiter, kemudian adanya $e$ learning, e-commerce dan e-banking menjadi media baru beraktivitas yang selama ini dilakukan secara fisik.

Perubahan revolusioner di atas dalam realitasnya tidaklah selalu berefek positif, karena hasil karya teknologi dikenal selalu berwajah ganda, yakni di satu sisi memberikan manfaat yang besar bagi kehidupan manusia, namun di sisi lain juga memberikan kemudahan, bahkan memperluas tindak kejahatan secara global. Perkembangan teknologi senantiasa membawa dampak secara langsung maupun tidak langsung, baik dalam arti positif maupun negatif, dan akan sangat berpengaruh terhadap setiap sikap tindak dan sikap mental setiap anggota masyarakat. ${ }^{3}$ Pada perspektif kriminologi, teknologi bisa dikatakan sebagai faktor kriminogen, yaitu faktor yang menyebabkan timbulnya keinginan orang untuk berbuat jahat atau memudahkan terjadinya kejahatan. ${ }^{4}$

Berdasarkan uraian di atas, maka penulis akan memaparkan mengenai bagaimana cara supaya semua infrastruktur hukum yang selama ini dibangun siap menghadapi problematika di dunia maya (era digital)?

\section{B. Pembahasan}

Setelah kemerdekaan, Indonesia bertekad untuk membangun hukum nasional yang berdasarkan kepribadian bangsa melalui pembangunan hukum. Secara umum hukum Indonesia diarahkan ke bentuk hukum tertulis. ${ }^{5}$ Konstruksi hukum yang selama ini berlaku dibangun dari paham positivisme yang bersifat formal, tindakan fisik dan berdaya jangkau yurisdiksi nasional berdasarkan batasan territorial. Kini, legal meta-narative akan diuji kemampuannya menghadapi teknologi informatika. Kehidupan telah semakin marak dalam format-formatnya yang global, seolah menawarkan alternatif baru yang tidak hanya mengatasi aspek-aspek kehidupan, termasuk kehidupan hukum nasional, melainkan juga untuk memarakkan kehidupan global, bahkan juga seakan-akan hendak menebarkan lokalisme dimana-mana. ${ }^{6}$

Kehadiran hukum modern saat ini dilatarbelakangi oleh sejarah masa lalu yang melibatkan hubungan timbal balik antara hukum dengan masyarakat dan perkembangan negara modern. Modernitas ini memiliki ciri-ciri, sebagai berikut: ${ }^{7}$

a. Mempunyai bentuk tertulis.

b. Hukum itu berlaku untuk seluruh wilayah Negara.

c. Hukum merupakan instrumen yang dipakai secara sadar untuk mewujudkan keputusan-keputusan politik masyarakatnya.

Hukum dengan ciri khasnya yang harus tertulis memang menjadi kebutuhan negara modern yang semakin kompleks dan bidang yang beragam. Hukum tertulis kemudian menjadikan hukum harus formal, kaku, tidak fleksibel, dibuat oleh penguasa yang berwenang dan tidak terkait sama sekali dengan kualitas kepastian hukum dan keadilan. Keberlakuan hukum di zona negara

\footnotetext{
2. Yasraf Amir Piliang, "Public Space dan Public Cyberspace: Ruang Publik dalam Era Informasi”, tersedia di website http://www.bogor.net/idkf/idkf-2/public-space-dan-public-cyberspace-ruang-publik-dalam-era inf, diakses pada 3. tanggal 25 April 2012.

4. Andi Hamzah, 1992, Aspek-Aspek Pidana dibidang Komputer, Jakarta, Sinar Grafika, hlm. 10.

5. Abdul Wahid dan Mohammad Labib, 2005, Kejahatan Mayantara (Cybercrime), Bandung, Refika Aditama, hlm. 59. Renny N.S. Koloay, "Perkembangan Hukum Indonesia Berkenaan Dengan Teknologi Informasi Dan Komunikasi”,

6. Jurnal Hukum Unsrat, Vol. 22, No.5, Januari 2016, hlm 18.

6. Sutandyo Wignjosoebroto, 2008, Hukum Dalam Masyarakat, perkembangan dan masalah, Malang, Bayumedia 7. Publishing, hlm 244
}

Satjipto Rahardjo, 1982, Ilmu Hukum, Bandung, Citra Aditya Bakti, hlm. 213-214 
menujukkan hukum modern sebagai hukum nasional yang didasari oleh teori kedaulatan negara atas teritorinya. Terakhir, hukum tidak hanya menjadi instrumen legitimasi, tetapi juga social engineering. Harapannya hukum dapat melayani kebutuhan masyarakat modern yang semakin komplek dan beragam. Hukum ternyata tidak serta merta dapat seiring sejalan dengan perkembangan masyarakat dan teknologi yang mengikutinya.

Sebagaimana diungkap sebelumnya, hukum yang saat ini berlaku dilatarbelakangi oleh sejarah dan kehidupan sosial masa lalu, seperti di kawasan Eropa dengan dominasi paradigma modern yang positivistik dan melahirkan konsep Rule of Law. Akibatnya, hukum bersifat formal, prosedural, berlaku nasional dan dominasi negara dalam merekonstruksi dan menerapkan hukum. Kondisi ini terus mewarnai proses pembuatan dan penegakan hukum di Indonesia sampai saat ini yang telah memasuki era digital. Hukum yang terlalu formal, kaku dan tidak fleksibel, serta berlaku nasional mengalami kesulitan mengakomodir perkembangan teknologi informatika yang begitu cepat.

Hukum yang selama ini dibangun dengan konstruksi asas legalitas, asas territorial, dan perbuatan dipandang sebatas secara fisik. Hukum juga semakin pragmatis dengan tujuan seolah mengakomodir semua problem di masyarakat atau mengandung tujuan ekonomi politik penguasa yang semuanya jelas bersifat sesaat dan setempat. Kehadiran Undang Undang tentang Pornografi dan Undang Undang tentang Informasi dan Transaksi Elektronik, misalnya, yang bertujuan untuk menanggulangi maraknya pornografi, pornoaksi serta berbagai cybercrime justru tidak terlihat hasilnya dan kontraproduktif. Undang-undang yang terkait dengan sumber daya alam (SDA), seringkali menunjukkan ketidakberpihakannya kepada masyarakat, namun kepada kepentingan ekonomi politik penguasa dengan kapitalis asing. Di sini hukum hanya dibuat oleh aktor-aktor yang berkepentingan.

Hukum berparadigma modern dengan karakter dan doktrin-doktrinnya yang selama ini menjadi legal-metanarative yang diterima, kini mengalami ketidakberdayaan ketika berhadapan dengan perkembangan teknologi informatika, yang lebih cenderung memerlukan keragaman micro-narrative dalam memaknai hukum. Sehubungan dengan hal tersebut, Jean Francois Lyotard menolak pradigma meta-narrative karena dalam masyarakat terdapat keragaman perbedaan, keragaman aspirasi, keyakinan dan keinginan, sehingga perlu dimunculkan paradigma baru, yakni postmodern yang menunjukkan adanya narasi-narasi kecil (micro-narrative) guna menyelesaikan persoalan yang terjadi di masyarakat.

Cyberspace yang dikenal pula dengan istilah dunia virtual dan dunia mayantara memiliki karakteristik, yakni without boundary, 24-hours on-line, Interactive, Hyperlink, No license, No censorship and Efficiency. ${ }^{8}$ Ke semua karakter tersebut menjadi permasalahan tersendiri dalam konteks hukum, khususnya terkait berbagai hubungan perdata maupun ketika terjadi kejahatan.

Munculnya cyberspace dengan cybercommunity-nya telah memindahkan sebagian aktivitas dan perilakunya di dunia nyata ke dunia maya. Jelas di sini teknologi mempengaruhi perilaku masyarakat. Menurut Satjipto Rahardjo, perkembangan teknologi sangat mempengaruhi pola-pola hubungan dalam masyarakat. ${ }^{9}$ Lebih dari itu, Sudarto secara jelas menyatakan bahwa kemajuan teknologi mempunyai pengaruh terhadap pola kejahatan. ${ }^{10}$ Barda Nawawi Arief menyebutkan lebih eksplisit lagi bahwa Cybercrime merupakan salah satu sisi gelap dari kemajuan teknologi yang mempunyai dampak negatif sangat luas bagi seluruh bidang kehidupan modern saat ini. ${ }^{11}$ Ketiga

\footnotetext{
8. Budi Agus Riswandi, 2003, Hukum Dan Internet Di Indonesia, Yogyakarta, UII Press, hlm. 15-21

9. Satjipto Rahardjo, 2009, Penegakan Hukum (Suatu Tinjauan Sosiologis), Yogyakarta, Genta, hlm 146

10. Sudarto, 1983, Hukum Pidana dan Perkembangan Masyarakat, Bandung, Sinar Baru, hlm 104

11. Barda Nawawi Arief, 2006, Tindak Pidana Mayantara: Perkembangan Kajian Cyber Crime Di Indonesia, Persada, Jakarta, RajaGrafindo, hlm. 1-2.
} 
pernyataan ini menunjukkan bahwa teknologi turut merubah pola-pola hubungan masyarakat yang selama ini dilakukan, termasuk menjadikannya sebagai media kejahatan.

Typoo writer merupakan mesin ketik pertama yang dibuat tahun 1829 menjadi alat tercanggih di zamannya. Tahun 2010, kemudian muncul IPAD yang jauh lebih canggih. Perubahan yang begitu cepat dan sangat berbeda ini menggeser pula perilaku manusia dalam bersosialisasi dan berinteraksi. Dulu jual beli, kontrak, perjanjian, sewa menyewa dilakukan secara fisik dan terjadi transaksi pertukaran uang dan barang. Di ruang cyberspace, semua transaksi jual beli, serta promosinya melalui iklan dilakukan secara online dan mengabaikan semua kewajiban administrasi, pajak dan hukum keperdataan yang diatur negara. Ecommerce menjadikan proses rumit perdagangan antar provinsi, bahkan antara negara menjadi lebih sederhana, cepat dan efisien. Beberapa diantaranya tidak perlu memiliki perusahaan resmi, namun cukup memiliki blog jual beli barang.

Permasalahan yang sama juga terjadi pada hak atas kekayaan intelektual (HKI) yang sulit dijaga oleh negara melalui hukumnya. Semua dapat dicopy, diperbanyak dan dibajak tanpa izin pemegang hak cipta, terlebih lagi membayar royaltinya. Mulai dari buku, lagu, film sampai dengan berbagai software bebas saja diakses antar negara untuk kemudian diperbanyak, disebarkan dan diperjualbelikan. Di bidang kesusilaan, berbagai bentuk kejahatan dan pelanggaran kesusilaan juga terjadi. Berbagai bentuk fitnah, pencemaran nama baik sampai dengan perbuatan asusila juga terjadi. Fenomena cyberporn, cybersex dan cyberprostitution telah mengubah konstruksi hukum bahwa zina dan prostitusi juga dapat dilakukan via dunia maya, tanpa harus melakukan hubungan fisik.

Berbagai dampak perkembangan teknologi telematika di atas menjadi tantangan bagaimana berhukum di era digital yang tidak mengenal batas negara. Bagaimana hukum modern fleksibel untuk dapat terus beradaptasi terhadap perkembangannya yang begitu cepat. Hukum dituntut untuk dapat melindungi hak-hak warga negaranya dalam aktivitas dunia maya, seperti penipuan dalam e-commerce, jaminan perlindungan HKI dan terhindar dari segala bentuk konten yang menyesatkan dan berbau pornografi. Konteks keberlakuan hukum nasional yang sektoral memerlukan reorientasi secara global, karena internet tidak hanya menghubungkan antar orang atau orang dengan negara dalam satu negara, namun seantero bumi.

Ketidakmampuan hukum modern dalam menjangkau problem-problem di atas, membuat dunia maya dianggap sebagai dunia tanpa hukum. Onno W. Purbo menyatakan bahwa internet terlihat oleh sebagian besar orang, pengguna, pengamat sosial sebagai dunia tanpa batas, tanpa aturan, dunia kebebasan. Hal inilah yg menyebabkan terjadinya berbagai bentuk kejahatan dan pelanggaran di dunia maya. ${ }^{12}$ Prinsipnya, dunia maya tidak terlepas dengan realitas dunia nyata, karena orang atau korporasi yang terlibat hidup di dunia nyata. Mereka hanya menghadirkan diri dan terlibat dalam aktivitas di dunia maya.

Dunia maya merupakan media dan cybercommunity terikat dengan hukum. Menurut Barda Nawawi Arief, "perusakan dan pencemaran informasi di mayantara" (dapat disebut sebagai cyberdamage dan cyberpollution) bagian dari environmental crime, yang perlu dicegah dan ditanggulangi. Upaya ini menurutnya jika dilihat dari sudut criminal policy, upaya penanggulangan kejahatan (termasuk cybercrime dan cyberporn) harus dilakukan dengan pendekatan integral/sistemik, yaitu pendekatan penal (hukum pidana), pendekatan teknologi (techno prevention) karena cybercrime sebagai salah satu bentuk dari hitech crime, pendekatan budaya/kultural, pendekatan moral/edukatif (terlebih delik kesusilaan) dan pendekatan

12. Abdul Wahid dan Mohammad Labib, Op.cit., hlm. 33

13. Barda Nawawi Arief, 2003, Kapita Selekta Hukum Pidana, Bandung, Citra Aditya Bakti, hlm 250 
global/kerjasama internasional. ${ }^{14}$

Di sisi lain ,masyarakat terdiri atas beragam kelompok, yang antara satu dengan lain mempunyai keragaman nilai, paham,persepsi dan pendapat, yang sering kali terjadi di suatu kelompok, suatu perbuatan merupakan perbuatan terlarang, namun di kelompok lain bukan merupakan perbuatan terlarang. Apabila perbutan tersebut dilakukan melalui dunia maya, menjadi suatu persoalan apakah perbuatan tersebut merupakan perbuatan melanggar hukum atau tidak. Undang undang, apabila dipandang sebagai legal meta-narative dan dituntut untuk menyelesaikan masalah ini niscaya akan mengeluarkan keputusan yang tidak sesuai dengan rasa keadilan masingmasing kelompok yang mempunyai keragaman budaya tersebut.

Pendekatan budaya/kultural, moral, edukatif dapat dilaksanakan bila pemikiran hukum modern yang memposisikan hukum sama dengan undang-undang, yang berkarakter legal meta-narative yang implementasinya menggunakan "syllogisme", yakni hukum yang diformalkan dalam bentuk undang-undang sebagai premis mayor,akan digunakan untuk menyelesaikan suatu kasus sebagai premis minor, kemudian disimpulkan dalam putusan hukum sebagai konklusi,dilakukan dekonstruksi serta rekonstruksi.

Penggunaan "syllogisme" dalam mengatasi masalah yang terjadi pada cyberspace sangat sulit mendapatkan putusan yang adil, sebagaimana terjadi pada kasus Prita, yang dalam proses Peradilan Pidana maupun Peradilan Perdata dinyatakan melakukan tindak pidana ataupun melakukan tindakan yang merugikan nama baik Rumah Sakit Internasional OMNI melalui dunia maya (cyberspace), karena menulis keluhan atas perawatan Rumah Sakit tersebut yang dipandang berbuat tidak profesional kepada dirinya saat menjadi pasien, sebagaimana ditentukan dalam Undang-Undang tentang Informasi dan Transaksi Eektronik (UU ITE). Masyarakat luas menolak Prita dipidanakan maupun digugat oleh Rumah Sakit
Internasional OMNI dengan gerakan dukungan melalui dunia maya serta pengumpulan uang guna mendukung Prita membayar ganti rugi sebagaimana gugatan Rumah Sakit Internasional OMNI.

UU ITE yang oleh Aparat Penegak Hukum dipandang sebagai legal metanarative, dan digunakan sebagai premis mayor, mendapat tantangan keras dari masyarakat, karena menurut masyarakat Prita tidak melanggar UU ITE, baik pidana maupun perdata. Pemaknaan UU ITE antara Aparat Penegak Hukum dan Rumah Sakit OMNI di satu pihak dengan Prita dan Masyarakat di pihak lain ternyata berbeda. Hal tersebut menandakan perlu dilakukannya "dekonstruksi" dan "rekonstruksi" pemikiran/paradigma. Hal ini tidak akan dapat diselesaikan dengan (paradigma) hukum modern, dan hanya dapat diselesaikan dengan paradigma post-modernism yang mengakui adanya perbedaan "pemaknaan" terhadap suatu undang-undang bagi setiap pemangku kepentingan, sehingga diutamakan penyelesaian yang saling menerima dan memberi sebagai solusinya.

Paradigma post-modernism memposisikan konstitusi dan peraturan perundang-undangan bukan sebagai legal meta-narative, namun merupakan "bingkai" dalam kehidupan bermasyarakat, sedangkan "isi" diberikan kebebasan para pemangku kepentingan untuk "memberikan makna" sesuai dengan konteks. Paradigma post modernism dengan demikian menuntut para pemangku kepentingan menyelesaikan masalah mereka sendiri berlandaskan pemaknaan terhadap UU terkait, yang bila diperlukan menggunakan pihak ketiga sebagai "penengah", namun sedikit mungkin menyelesaikan kasus melalui peradilan yang menitik beratkan birokrasi, proses dan kepastian yang sering mengesampingkan keadilan dan kemanfaatan serta harmonisasi bagi para pemangku kepentingan.

Kasus Prita menuntut adanya pergeseran paradigma, dari paradigma hukum modern yang menitik beratkan pada kepastian hukum formil menuju paradigma hukum

\footnotetext{
14. Barda Nawawi Arief, Tindak Pidana Mayantara, Op.cit, hlm 183
} 
post-modernisme, yang menitik beratkan pada kepastian hukum materiil, mengacu pada realitas yang ada di masyarakat. Keluhan Prita atas pelayanan yang diberikan oleh Rumah Sakit OMNI pada sat ia sakit yang dipandang tidak sesuai dengan standart pelayanan kesehatan melalui dunia maya yang ditujukan kepada sahabatnya, dipandang oleh Prita dan masyarakat merupakan sesuatu yang wajar, biasa dan lumrah, sehingga bukan merupakan tindak pidana ataupun perbuatan melanggar hukum perdata sebagaimana diatur dalam UU ITE. Pihak RS OMNI mempunyai pandangan lain, dan berpendapat perbuatan Prita merupakan perbuatan melawan hukum, baik perdata maupun pidana sebagaimana diatur dalam UU ITE.

Paparan tersebut menunjukkan, bahwa penyelesaian masalah hukum di era digital akan sangat sulit mendapatkan nilai kemanfaatan dan keadilan apabila para pemangku kepentingan masih menggunakan "paradigma hukum modern" yang "positivistik" serta meletakkan undang undang sebagai legal-metanarative, namun hendaknya mulai melakukan pergeseran paradigma ke post-modernisme yang mengedepankan adanya "pemaknaan aturan" sesuai dengan konteks.

Respon khalayak/masyarakat terhadap kasus Prita dengan paradigma post modernisme dengan terjadinya dialog pada public space melalui dunia maya (face book, internet), mass media, media elektronik, serta langkah empirik dengan "gerakan pengumpulan koin untuk Prita" ternyata mampu menggerakkan Lembaga Peradilan di tingkat Kasasi menyelesaikan perkara sesuai dengan aspirasi masyarakat yang ada, yakni menyatakan bahwa Prita tidak melakukan perbuatan melawan hukum, baik secara perdata maupun pidana.

\section{Simpulan}

Hukum modern dengan segala doktrinnya sebagai legal meta-narative yang mewarisi hukum masa lalu kini lemah ketika menghadapi arus teknologi informatika yang telah melahirkan cyberspace. Diperlukan terobosan, perubahan paradigma, fleksibilitas, yurisdiksi universal, harmonisasi dan kerjasama global, pengakuan lokalitas yang beragam,sehingga hukum Negara (undang-undang) dapat berlaku di dunia maya, bukan sebagai legal meta-narative, namun sebagai bingkai terhadap setiap permasalahan yang muncul. Penyelesaian masalah cyberspace sangat sulit diselesaikan dengan menggunakan (paradigma) hukum modern dengan doktrin legal meta-narative berdasarkan methode "syllogisme"; dan akan lebih mudah serta mencerminkan rasa keadilan masyarakat, bila menggunakan paradigma post modernism yang memberikan keleluasaan (flexibilitas) bagi setiap pemangku kepentingan untuk memaknai hukum (tertulis) sesuai "konteks", dengan memperhatikan local wisdom, dengan seoptimal mungkin memanfaatkan public space sebagai arena untuk menemukan "kesepahaman" antara para pihak.

\section{Daftar Pustaka}

Arief Barda Nawawi, 2003, Kapita Selekta Hukum Pidana, Bandung, Citra Aditya Bakti.

Arief Barda Nawawi,, 2006, Tindak Pidana Mayantara: Perkembangan Kajian Cyber Crime Di Indonesia, Persada, Jakarta, RajaGrafindo.

Edi Atmaja AP, "Kedaulatan Negara Di Ruang Maya: Kritik UU ITE Dalam Pemikiran Satipto Rahardjo", Jurnal Opinio Juris, Vol. 16, Mei-September 2014

Hamzah Andi, 1992, Aspek-Aspek Pidana dibidang Komputer, Jakarta, Sinar ${ }^{13}$ Grafika.

Koloay Renny N.S, "Perkembangan Hukum Indonesia Berkenaan Dengan Teknologi Informasi Dan Komunikasi", Jurnal Hukum Unsrat, Vol. 22, No.5, Januari 2016

Rahardjo Satjipto, 1982, Ilmu Hukum, Bandung, Citra Aditya Bakti.

Rahardjo Satjipto, 2009, Penegakan Hukum (Suatu Tinjauan Sosiologis), Yogyakarta, Genta. 
Riswandi Budi Agus, 2003, Hukum Dan Internet Di Indonesia, Yogyakarta, UII Press.

Sudarto, 1983, Hukum Pidana dan Perkembangan Masyarakat, Bandung, Sinar Baru.

Wahid Abdul, dan Mohammad Labib, 2005, Kejahatan Mayantara (Cybercrime), Bandung, Refika Aditama.

Wignjosoebroto Sutandyo, 2008, Hukum Dalam Masyarakat, perkembangan dan masalah, Malang, Bayumedia Publishing.

Amir Piliang Yasraf, "Public Space dan Public Cyberspace: Ruang Publik dalam Era Informasi", tersedia di w e b s i t e ht t p : / / w w w . bogor.net/idkf/idkf-2/public-spacedan-public-cyberspace-ruang-publikdalam-era inf, diakses pada tanggal 25 April 2012 